\title{
IMPACT OF DIVIDEND PAYOUT ON FIRM'S PERFORMANCE UNDER LOW GROWTH OPPORTUNITIES
}

Taymoor Ali ${ }^{1}$, Muhammad Kashif Khurshid ${ }^{2 *}$, Adnan Ali Chaudhary ${ }^{3}$

${ }^{1}$ Head Teacher, District Education Authority Jhang, School Education Department Punjab, Pakistan; ${ }^{2 *}$ Lecturer, National University of Modern Languages (NUML) Islamabad, Pakistan; ${ }^{3} \mathrm{Ph} . D$., Scholar, Business Administration, Lyallpur Business School (LBS), GC University Faisalabad, Pakistan.

Email: ${ }^{1}$ alitaymoor321@gmail.com, ${ }^{2 *}$ mkkhurshid@numl.edu.pk, ${ }^{3}$ adnan7643@yahoo.com

Article History: Received on $18^{\text {th }}$ May 2021, Revised on $9^{\text {th }}$ June 2021, Published on $23^{\text {rd }}$ June 2021

\section{Abstract}

Purpose of the study: The objective of the study was to investigate the relationship of the dividend payout on a firm's performance under low growth opportunities from the manufacturing sector of Pakistan.

Methodology: A sample of 251 firms out of 378 manufacturing firms listed at the Pakistan Stock Exchange (PSX), have been carefully chosen for the era of ten years from 2006 to 2015. The secondary data was obtained from the firm's web financials and analysis of financial statements, published by the statistics department of the State Bank of Pakistan. For the persistence of investigation panel data (fixed effect) analyses were employed in this study.

Main Findings: The fallouts of the analysis revealed that the dividend payout ratio has an insignificant relationship with the firm's performance in the low growth perspectives of the study.

Applications of this study: The findings of the study are helpful for the financial managers of the firms facing low growth opportunities. Furthermore, the investors in capital markets can use the findings of this while investing.

The originality of this study: The study focussed on the role of low growth opportunities while studying the nexus of dividend pay-out and the firm's financial performance which inherits the novelty and originality of the study.

Keywords: Dividend Payout, Growth Opportunities, Firm's Performance, Firm's Size.

\section{INTRODUCTION}

The effect of dividend payout patterns of corporations on the firm's performance is still the subject of a focal point of the research era with innovative dimensions by the researchers. These financial indicators of firms are the milestones for all the stakeholders at all levels and are incorporated as a major part of the literature in finance that may be referred to. The former study, conducted in this regard, revealed that the value of the corporations persist unaffected by the decisions regarding the dividend disbursement of firms in the capital market with perfect perspective, therefore besides the conventional belief that value of firms may be improved by the distribution of dividend payments. In the perfect aspect of the capital market, all of the above financial indicators do not influence the corporate value and corporate performance because of efficient markets and symmetry of financial information in this regard (Miller \& Modigliani, 1961).

On the conflicting, Gordon, (1963) and (Lintner, 1962) stated that in the real world of capital market at imperfect level, steady and even patterns of dividend payouts intensify the corporate value. Since most of the executives observe that a decrease in the dividend payouts stretches negative influence on the corporate value of firms in a perfect market. In the real world, different firms face different market situations due to imperfect markets and asymmetry of financial information to stakeholders that cause financial constraints to firms. These financial constraints are resulted in opportunities and threats to firms according to perception based on the availability of resources.

The payout policy of dividends is unique to the major estimates accessible to the management of firms for diminishing agency cost issues. Explicitly, it is projected that by persuading external monitoring, dividends may cause to increase in the business deal costs allied with the raising of external funds although at the same time decrease in agency costs. Secondly, they considered the implications of affiliation in the business group for dividend payout decisions through including cluster affiliation and collaboration terminologies into their research model (Black et al., 2014; Ghemawat \& Caves, 1986).

Baker and Wurgler, (2004) expressed that one of the foremost aspects of dividend disbursement policy may be to attract latent and actual stockholders to the market. In the finance research era, it's become a mandatory prospect to drive the business organization efficiently and competently in diverse eras and to address convincingly that dividend disbursement policies have a contributive effect on the performance of the business organization. Dividend disbursement policy contributes an effective and vital part for an increase in economic resources then compatibility to work successfully in the fluctuating tendencies of financial arcades.

Numerous scholars had discovered that how corporate financial performance was related to dividend payout policies. Muchira, (2013) found a substantial optimistic relationship between dividend policy (DPO) and corporate financial performance (ROA). Rafindadi and Bello (2019) analyzed the study \& their verdicts exposed that dividend policy had no impact on the firm performance in the long run. The effect of dividend policy on corporate performance was higher in 
the developed market i.e. Finland as compared to the developing market i.e. Nigeria (Olufade, 2018). The dividend policy did not impact the corporate performance in long run (Rafindadi \& Bello, 2019).

Senevirathna (2019) incorporated listed firms in the Colombo stock market in their research. It was discovered that the effect of dividend policy on firms' performance was significant \& positive. It was also revealed in research that If the corporate performance goes high, the stockholders' earning will also high. Finally, Wijekoon originated the conclusion that dividend policy provides indications to prospective investors. The prospective potential investors who are ready to invest in CSE may use dividend policy to assess whether this sector appropriates or not to invest.

Mamaro and Tjano (2019) researched the association of dividend payout for firm financial performance. They concluded that net profit margin had a substantial optimistic correlation with a dividend payout ratio \& an adverse association for firms size \& growth in the dividend payout ratio. The firm's dividend payout \& liquidity had an adverse association with financial performance. Additionally, the leverage had an inverse relationship with a dividend payout. Finally, academic outcomes revealed that the large scale firms pay fewer dividends, the utmost lucrative firms, dispense high dividends while low growth firms pay a higher profit.

Chelimo, (2018) investigated the effects of steady dividend policy on firm financial performance incorporating the Serena group of the hotel in Kenya. According to the analysis, it was concluded that the high earning per share (EPS) \& high dividend per share (DPS) resulted in an upsurge of stock price which ultimately leads to higher financial performance. As per analysis, earning and dividend policy affected the value of stocks in the long run with a significant and constructive association. If dividend payout had increased, its effect increases the stock prices \& finally, it appears to better financial performance.

In developing countries like Pakistan, most stakeholders are associated with short-term benefits due to the volatility of capital markets. The stock market of Pakistan is the most liquid and volatile market of Asia, which is not only affected by economic and financial indicators as well as non-financial indicators like terrorism, corruption, etc. Due to these patterns of volatility, firms in Pakistan face potential opportunities for growth that affect the firm's value and performance.

Most of the researchers have been focusing on the association between dividend disbursement strategy and the performance of firms from different sectors in the country. But no one realizes the growth patterns as a potential element that influences the value and fiscal performance of the business corporations. So, this research study is two-dimensional with low growth and high growth in firms. This study would also be helpful to determine whether, patterns of shareholdings and French-Fama dynamics like corporation's size, market to book ratio, deliver further details for the performance of business firms under the same situation outside the conventional theories or not.

Dividend policies are developing and expressing the dividend mechanism of the firm in financial affairs. Dividend policies are generated in form of incremental rewards. Thus, research-oriented results proved that dividend disbursement policies have a dominant role in the financial affairs of business firms (Yao et al., 2011). Dividend payout tactics are exclusively the dividend disbursement rates and have a significant positive effect on opportunities faced by developing economies and developing firms. The dividend payout rates also supportive to a significant part for the financial performance of business firms in evolving and developing markets (Glen et al., 1995; Qureshi et al., 2015).

\section{Need of the study}

This research study is needed for the commercial and corporate investors who are interested in the manufacturing firms listed at PSX. The dividend payout has an association with the performance of manufacturing firms and decisions regarding capital budgeting that are an imperative perception for stakeholders who are looking for trustworthy informative evidence, to measure the firm's performance in the future.

This study may also be beneficial for the management of the companies as they will have to keep notice of this association while forming their policies regarding firm's performance by considering the disbursement patterns as well as improving operating cash flows for making their corporations capable to disburse regular and high dividend payouts that will eventually promote the market value of their equity stocks.

This research study would also be helpful to legislative authorities of corporate laws to dishearten concentrated institutional and insider shareholdings in corporations and to give due security to minority stockholders against expropriation of respective rights.

For professionals, it will assist to consider that how numerous financial decisions that may influence the corporate earnings accessible to stockholders and for the investment prospects under different situations. For practitioners, it will also portray some knowledgeable considerations regarding the encounters that may arise due to the pronouncements engaged under specific proprietorship configuration inside the corporation.

\section{LITERATURE REVIEW}

\section{Theory of Dividend Irrelevancy}


The theory of dividend irrelevancy was explored by Modigliani and Miller (1958) which describes that dividend payout policy does not influence the value of the firm as well as the price of the stocks in an efficient market. They claimed that the value of a corporation is influenced by the level of profits generated by assets within corporate firms while it doesn't reliant on the level of dividend dispersed. This former viewpoint was centred on the supreme suppositions of the efficient and perfect nature of the capital market. They presumed that there would be; there are no alterations between the taxes dividends payouts and capital profit, there is no cost regarding brokerage, all of the stockholders will be provided awareness of symmetry of market information. All of these conventions were impractical \& were not being right (Miller \& Modigliani, 1961).

Dividend policies are significant and operative when they are being established and monitored supportively and influentially, from time to time. The logical results of the dividend policies provide a proper mechanism to distribute the dividend, once the firm earns to such an extent that it may have enough money to pay dividends. The findings were showing that the firms are in a better and strong financial position, which indicated that corporations were performing well. Thus, research-based analysis substantiated that dividend policies of firms are considerably influencing a firm's performance and new potential shareholders are interested in a firm (Bhattacharya, 1979). Dividend policies are a great tool that is used to influence the investment decisions of the shareholders regarding the firms, which were also associated with agency costs in corporations. In retort to the business affiliations and financial outcomes, it is highly supportive to devise well-suited policies for the betterment and value development of firms (Easterbrook, 1984; Jensen, 2009).

A research-based study had been conducted in Hong Kong during the period from 1995 to 1998 to observe the effect of dividend payout strategy on the fiscal performance of the firm empirically. The time-series data have been used and proved. The major findings are that dividend disbursement strategy has a significant positive relation to the firm's performance, but these results were evidenced in the small firms up to little extent; as firm's financial position through corporate performance is improved by the increase in the size of the corporation and supportive to dividend payment ratio efficiently (Chen et al., 2005; Zhou, 2001).

Ijaiya et al., (2014) ultimately discovered the relationship between dividend payout \& fiscal performance of listed companies in Nigeria. The judgments indicated an inconsequential association between dividend disbursement ratio and the financial performance of the listed and selected listed companies in Nigeria for the principal model, whereas the outcomes from the subsequent model expressed an inverse but significant relationship between dividend disbursement ratio and corporate performance estimated by earnings per share, indicating that corporate retained earnings as a source of growing their earnings per share. Based on the outcomes, the study endorses that a reduced but stable dividend payout should be maintained by firms to improve market valuation, internal finance, and maximization of shareholder wealth in the long run.

\section{Tax Preference Theory}

Rendering to this philosophy, low payouts of dividend reduces the cost of equity, upsurges the market price of a stock, and therefore raises the value of a firm. This postulate is founded on the supposition that capital gains are being taxed at lower proportions than disbursed dividends. Furthermore, dividends are being taxed at higher rates instantly, while taxes with lower rates on the capital profits are postponed even the stock of securities is being sold actually. These tax benefits of capital profits for dividend ready the investors to favor companies which retain most of their earnings rather than to distribute it as dividend and are not willing to pay high tax. Consequently, a short dividend disbursement ratio will decrease the cost of investment and upsurges the price of the share (Litzenberger \& Ramaswamy, 1979).

\section{Dividend \& Firm's Performance}

Some other contrary studies like Farsio et al. (2004) presented the irrelevancy of dividend disbursement strategy in measuring performance and determining the value of firms. They reasonably believed that considerable reinvestment of retained earnings (contrary to dividend payout) would improve earnings growth faster in the future. For example, they remarked that a rise in dividend payments may be a result of a decay in surplus funds in a firm that was to be reinvested for growing the corporate earnings. Corporations that distributed large dividends without reinvestment considerations, mostly experience a decline in future earnings. Another situation is that an upturn in dividends may be associated with the policy of management to satisfy the investors and avert them from the sale of stocks at times when current losses were projected to continue and earnings are expected to decline or in the future. A negative association is analyzed between dividend disbursement and corporate future earnings.

One of the main objectives of dividends may be to attract actual and potential stockholders. In the finance era one of the major requirements to drive the corporation efficiently and effectively in diverse periods should also be addressed in an applicative manner realistically, was the dividend payout policy that has a contributive effect on a firm's performance. The dividend payout strategy played an efficient and effective role to improve compatibility and resources to drive expressively in the changing trends of financial markets (Baker \& Wurgler, 2004).

A research-based study evidenced that dividend payout strategy defines corporate dividend disbursements in many countries like UK, Canada, USA, franc, Germany, and Japan that the inclination regarding dividend payouts was highly and positively affected the firm's performance. The position of firms with high dividend payouts stimulated the firm's 
performance positively in the form of more effective outcomes as well as a profitable position. The corporations which were beyond this realm were ascertained with low growth tendency and less profitable position as well fewer dividend disbursements. Thus, the influence of the dividend payment ratio was high and positive towards the resulting position (Denis \& Osobov, 2008).

Japanese corporations have explored the link between the volume of foreign investments on firm performance and dividend payout strategy. It was analyzed that a high level of foreign investments affected the corporate dividend payout strategy which in turn affected the corporate performance. Therefore, a positive and significant correlation was examined between foreign investment, dividend disbursement strategy, and firm performance (Baba, 2009; Reddy et al., 2008).

The research study aimed to develop an association between dividend payments and corporate performance regarding listed companies at Nairobi Stock Exchange. The judgments indicated that dividend disbursement was a key factor that affected corporate performance. A strong and positive association is observed with the help of regression analysis. Consequently, it was indicated that the dividend strategy was pertinent. It may be determined, centered on the outcomes of the study that dividend strategy is considered as important so that management ought to give sufficient time in devising the dividend strategy that will improve the corporate performance and hence the stockholder's value (M'rabet \& Boujjat, 2016).

From the outcomes of the study and existing research work, it is observed that the average dividend payments paid by banks were $24.65 \%$ over the study period. It is also apparent that banks increase their performance by paying dividends. The outcomes also strengthen earlier verdicts that the size of a bank, leverage, and bank growth improve the performance of banks. The age factor expresses the mixed results. Normally, the findings are in tandem with previous studies that there is an effect of dividend disbursement strategy firm value and firm performance (Agyei \& MarfoYiadom, 2011).

The value of firms turns to be important \& fundamental when it appears to the public that is a source for investing decision. The objective was established to assess the impact of dividend policy \& intellectual capital on the firm's profitability as well as the firm's value based on the firms from the automotive subsector listed on the Indonesia Stock Exchange (IDX) from 2010 to 2019. The data analysis was based on the Sobel test \& Path analysis. It was indicated that the value of firms \& profitability is not influenced by dividend policy significantly (Kadim et al., 2020).

Kurniawati and Khair 2020) expressed that dividend policy played a vital role for the corporate value as well as corporate profitability based on the corporations listed on the LQ-45 index from ISE for 2014 to 2019. Determining corporate profitability \& value is an imperative subject for every corporation because the financial stakes of investors \& corporations are being integrated herewith.

It was investigated the impact of dividend policy on firm performance \& stockholders' wealth creation for the listed Banks in the Nigerian stock exchange. Based on the data from the annual reports of the banks, descriptive statistics and multiple regression were employed for analysis. The outcomes expressed a positive association of dividend payout towards firm performance \& stockholders' wealth creation. It was recommended, based on the results that corporate management should guarantee that stockholders may get dividends as a return on their investment to persuade more investments (Ugwu et al., 2020).

It was also endorsed that management of manufacturing firms of consumer goods in Nigeria should guarantee wellstructured dividend policies because it will attract the investors for more investments that may increase the firm performance. The association between dividend policy \& financial characteristics was empirically analyzed. The verdicts exposed that Dividend per Share (DPS) had an adverse and insignificant association for Return on Assets (ROA), Return on Equity (ROE). The Dividend Payout Ratio (DPR) had an affirmative association for EPS. In this contextual, it was advised that the financial system of firms must be restructured to improve the operational efficiency of the financial market to determine the profitability of quoted firms via the dividend policy channel (Cyril et al., 2020).

There was a focus on the effect of dividend policy on the financial performance of firms from the health care sector that were listed on the Nigerian Stock Exchange for the period 2014 to 2018. The outcomes of the regression model were used to express a significant positive association between return on equity (ROE) and dividend per share (DPS), dividend cover (DC), dividend pay-out (DPO), and dividend yield (DY) at 5\% significant level. Based on the findings, it was concluded that dividend policy had employed significant impact on firms' performance for the years. So, it was recommended among all that firms that are willing to maximize value should ensure consistent increments for dividend payment that justifies the strong financial health of firms (Nangih et al., 2020).

As the importance of the subject matter of association between dividend policy and firm performance, one more effort was being made based on manufacturing companies listed at PSX for 2014 to 2017. Return on equity (ROE) and return on assets (ROA) were incorporated as dependent variables whereas earning per share (EPS), dividend payout ratio (DPOR) \& price-earnings ratio (PER) were incorporated as independent variables. The findings based on multiple regression analysis disclosed that all the independent variables had a positive association with dependent variables (Mohsin Hafeez et al., 2018). 
Zahid (2020) had studied the effect of corporate finance on firm performance by incorporating capital structure and the dividend policy as major pillars of corporate finance. He established the fallouts by judging the impression of capital structure \& dividend policy on firm performance from manufacturing and food sectors of PSE, BSE, DSE, and CSE covering the South Asian region. Panel-based regression findings explored the significant positive impact of dividend policy on firm performance wherever capital structure had revealed the negative impact on firm performance.

As per the recommendations of many research scholars, the firms should devise a dividend policy that will ensure better financial performance to improve on the dividend per share. It was also suggested that management should perform in the best interest of the stockholders that may resolve the agency problem. The fallouts presented that there is a significant \& positive relationship of dividend pay-out ratio; earnings per share and dividend per share towards return on equity (Ugwu et al., 2020).

According to empirical analysis from Amman Stock Exchange (ASE) to assess the relationship of ownership structure and dividends for the performance of manufacturing firms from Jordan, a hypothesis is tested from 2011 to 2015. It was observed that the major variables including dividend yield were worthy predictors for the firm's performance (Al-Sa'eed, $\underline{2018) .}$

To examine the association of financial performance for firm value with the intervening variable of dividend policy in an emerging market, Indonesia. It was observed that activity \& profitability had an optimistic effect, leverage has an adverse effect on the value of the firms. Subsequently, it was analyzed dividend policy had an optimistic effect on firm value. Leverage \& liquidity and did not affect the firm value, but activity \& profitability effect definitely on the firm value through intervening dividend policy. It was concluded that dividend policy fails the upshot of financial performance on firm value (Santosa et al., 2020).

At the business level, dividend policy had been one of the most important issues confronted by managers in business decision-making. So, in this regard, it was investigated the effect of dividend policy on the firm's financial performance in Nigeria for the period of 8years (2010-2017). Based on the multiple regression analysis it was discovered that dividend per share had positive with significant impact on ROA while an insignificant impact on return on equity. It was concluded that DPR had dual positive and negative effects on ROA and ROE respectively (Turais, 2020).

H1: There is a significant effect of the dividend payout ratio on a firm's performance under low growth opportunities.

\section{RESEARCH METHODOLOGY}

In this segment, research methodology was presented that was going to be implied in conducting out this research study. This chapter comprises of the research design, population, and sampling design containing the size of the sample, the nature of the technique used for data collection and drawing of a sample, conceptual framework, and data analysis which are all outlined to assist in achieving the objective of this research work that is to observe the association between patterns of shareholdings, dividend payouts, and firm's performance.

\section{Data Collection Sources and Sample Size}

In this study secondary data is to be used of 251 manufacturing listed companies on Pakistan Stock Exchange. Panel data is collected for this study from 2006 to 2015 for 10 years. In this study, the technique of systematic sampling is employed which was a technique of probability sampling. The population regarding this study was all the manufacturing firms from a non-financial sector which were listed at Pakistan Stock Exchange (PSX) which are more than 400 in total out of listed firms. The results are originated with the help of these statistical techniques. Descriptive statistics, correlation analysis-based fixed effect model used. This chapter also comprises the description of variables, development of a hypothesis, econometric model, and statistical explanation of variables incorporated in this study. Panel data of secondary nature is collected from balance sheet analysis or analysis of financial statements from the publications of the State Bank of Pakistan regarding the non-financial sector. Data of patterns of shareholdings is collected from the audited reports (financial statements) of respective firms that are accessible from their respective web-based financials.

\section{Econometric Modelling}

The following model is established to observe the effect of dividend payout on a firm's financial performance under the low growth opportunities estimated by Tobin $\mathrm{Q}$.

$$
F P(R O A) i t=\beta 0+\beta 1 D P O i{ }^{*} L G+\beta 4 \text { SIZEit }^{*} L G+\varepsilon
$$

\section{Definition of Variables in the Context of Literature}

\section{Firm's Performance}

It is incorporated as a dependent variable in the research study. A firm's performance states to an estimate of a firm's capability to produce income for a given period and it comprises a subset of the firm's efficiency that protects the financial and operational outcomes (Santos \& Brito, 2012). A firm's performance may be estimated and proxied by earnings produced by the firms in numeric values of profitability (Ouma \& Murekefu, 2012). One of the major advantages of accounting-associated profitability ratios is that they are mostly available in calculated forms by firms or 
official autonomous bodies at a general level. Therefore they are appropriate for listed and private corporations. Moreover, these are not prejudiced by the expectation in the market.

Return on equity (ROE) and Return on assets (ROA) are the most common proxies used to estimate in the prior shareholding literature. The ROE estimates the return on the investment from the firm's performance for equity owners, and ROA estimates the return on total assets for both debt holders and equity holders. Many existing research studies employed ROA as a proxy estimation for a firm's performance. In most cases, ROA has the same function as the ROE regarding the estimation of the firm's performance. Some existing studies that employed both ROE and ROA found similar coefficients for both proxy estimates. Nevertheless, ROE is the more sensitive proxy measure regarding the shareholding research, as Chaganti and Damanpour (1991) examined that ROA showed insignificantly and ROE showed a highly significant association with firm's performance in his research. The ROA is therefore more prevalent to a proxy estimation of the effect of overall shareholding on a company's performance.

In this research work, ROA is applied as a proxy measure for the firm's performance. It is in the form of a percentage calculated by net income from ordinary activities by the total assets of the corporation. ROA is used to generalize the results of this research work because ROA estimates the return on total assets for both debt holders and equity holders concerning the ordinary course of a firm's income. It is calculated by the following formula;

ROA $=($ Net Income $/$ Total Assets $) \times 100$

\section{Dividend Payout}

In this study, it is the independent variable. The dividend payout may be defined as the ability of firms to distribute profit to shareholders from the total profit earned in a business. The dividend payout strategy is the major predictor of the outcomes of this effort. It signifies the firm's capability to pay consistent or inconsistent type dividends during a period of study. Normally, such as firms pay a consistent dividend to stockholders, it regulates the arrangements of the firm's management to attain credibility in imperative to endure the strategy. They might thus approve such a policy whether to upsurge dividend payment strategy, static or dynamic dividend payment. As firms approve consistent dividend payout strategy, then the performance of a firm is more expected to upsurge during short term period while firms that approve inconsistent dividend payout strategy can upsurge efficiency but generally during the long term period because this type of firms likely tries to retain reserves for the undertaking of worthy developments about investments. According to this evidence, the dividends payout strategy can be considered by way of negatively or positively associated with the firm performance over the period. Several estimations are used to determine the dividend payment policy of a firm then for this tenacity mostly former scholars used estimation for dividend payout ratio to measure the dividend payout policy of firms. In this study, a formula is employed to determine the dividend payout by way of the total dividend paid by the firm, divided by the earnings per share.

\section{Dividend Payout Ratio $=($ Dividend per Share $/$ Earnings per Share $) X 100$}

\section{Firm's Size}

It is used as a control variable in the study. The size of the firm is frequently determined by taking the natural log of total assets. It is incorporated in this research work to assess the influence of independent variables on dependent variables by minimizing the effect of a firm's size after taking a natural log. In this way, it's become possible to find the association between the variables irrespective of the firm's size. Different philosophies support the optimistic as well as the pessimistic association between the firm's size and the performance of a firm. Firm size is determined by the following formula.

\section{Firm Size $=$ Natural Log (Total Assets)}

\section{Growth}

In this research study, firm growth will be estimated by the percentage change in assets. First of all, the percentage change in assets is calculated with help of collected panel data of selected firms on yearly basis. Then a median or average value is calculated with the help of these values percentage change in assets The firms possessing the change value above the median value, are considered with high growth opportunities. The firms possessing change value equal to or below the median value, are considered with low growth opportunities. De Jong (1999) also used this mechanism regarding the assessment of firms into the good and bad perspectives of investment opportunities. After measuring the firm's growth, the association is checked of dividend payout and corporate shareholding on the firm's performance under high and low growth opportunities.

\section{RESULTS AND FINDINGS}

This section is related to the assessment and analysis of the collected data. Subsequently, correlation analysis about variables is performed to ascertain the relations between the dividend payout ratio and a firm's financial performance. In the next stage, multiple regression analysis is undertaken on panel-based data to examine the degree and direction of associations amongst the variables by controlling the characteristics of the firm. The panel data-based technique (Fixed Effect Model) is the superlative technique for the estimation of both time series \& cross-sectional data simultaneously. 
Table 1: Growth-Descriptive Statistics of Low Growth Firms

\begin{tabular}{cccccc}
\hline Variables & N & Lowest & Highest & Mean & Std. Deviation \\
\hline ROA & 2510 & -63.3900 & 31.030 & 8.33488 & 24.0683 \\
\hline DPO*LG & 2510 & 0.000000 & 11.6667 & 0.135945 & 0.608602 \\
\hline Firm's Size*LG & 2510 & 0.0432200 & 19.5980 & 14.3362 & 1.81137 \\
\hline
\end{tabular}

Source: Based on authors' data analysis

\section{Descriptive Statistics}

The table-1 represents the normal distribution of data about 2510 observations, which portrays, the value of the firm's size variable expresses a high value of the mean, while the high value of standard deviation is expressed by return on assets. The ROA has a value of 8.33488 as mean, minimum value of-63.3900 and maximum value of 31.030 and the value of standard deviation for ROA is 24.0683. The DPO has a mean value of 0.135945 and the value of standard deviation is 0.608602 with the lowest value of 0.0000 and the highest value of 16.6667 . The firm's size has the value of 14.3362 as mean, the minimum value of 0.0432200 and maximum value of 19.5980 and value of standard deviation for firm's size is 1.81137 and the stated above descriptive statistics table regarding the normal distribution of data portrays that the untreated data has deficiencies of normal distribution. While all variables incorporated in the study which are departed from normalcy are skewed positively.

Table 2: Correlation Matrix

\begin{tabular}{llll}
\hline Variables & Firm's Size & DPO & ROA \\
\hline Firm's Size & 1 & & \\
\hline DPO & 0.0436 & 1 & \\
\hline ROA & 0.1135 & -0.0504 & 1 \\
\hline
\end{tabular}

Source: Based on authors' data analysis

\section{Correlation Matrix}

Table 2 reports that the correlation matrix between the variables which have been studied in this research, as the value of firm size showed that there is a positive correlation with return on asset. However, the dividend payout ratio is adversely correlated with the return on assets. In imperative to perform the panel data-based regression model, a full matrix is associated with correlations between all predictors (Dividend Payout) with the dependent variable (Firm performance). There is also indicated for correlations between the two independent variables \& their respective relationships through the dependent variable (ROA). The analysis from the correlational matrix explores that a significant correlation is not established amongst the independent variables.

Table 3: Fixed Effects Model

\begin{tabular}{llll}
\hline Variable & Co-efficient & t-value & P-value \\
\hline Constant & 89.2125 & 5.9801 & 0.00001 \\
\hline DPO*LG & -1.78529 & -1.3295 & 0.18380 \\
\hline Firm's Size*LG & 5.56047 & 5.2384 & 0.00001 \\
\hline R-squared & $\mathbf{0 . 3 5 6 6 8 1}$ & F(254, 2255) & $\mathbf{4 . 9 2 2 2 7 4}$ \\
\hline Adjusted R & $\mathbf{0 . 2 8 4 2 1 8}$ & P-value $(\mathbf{F})$ & $\mathbf{0 . 0 0 0 0}$ \\
\hline
\end{tabular}

Source: Based on authors' data analysis

** Significant at 0.05 level

\section{Fixed Effects Model}

Table 3 presents results based on panel-based regression estimates of the fixed-effect model. Primarily the model comprises four variables. The firm's size is appeared as significant at the conventional level for all firms for low growth opportunities. Other variables including dividend payout ratio are appeared to be insignificant. The results show that the firm's size has a significant \& positive association having a p-value (0.00001) is less than $0.05 \&$ an at-value (5.2384) is greater than the standard value of 1.96. It means that ROA increases up to (5.56047) by an increase in the value of a firm's size due to one unit.

There is a negative and insignificant association between DPO and ROA as the p-value (0.18380) is greater than $0.05 \&$ the $t$-value $(-1.3295)$ is less than the standard value of 1.96. According to the table, ROA decreases up to (1.78529) by the increase in dividend payouts due to one unit. So, the null hypothesis is recognized testifying that there is no significant impact of dividend payout on a firm's performance, and rejected the alternative hypothesis. The symbols of 
the coefficients are the same as expected. So, it becomes clear that the selected independent variables are contributing $(35.6681 \%)$ role for a firm's performance.

\section{DISCUSSION}

Table 3 presents the result of regression estimates based on Panel based fixed effect. The low-growth model includes four variables. Out of these variables, only the firm's size and managerial shareholding are appeared to be significant at the conventional level for all firms for low growth opportunities. Other variables including dividend payout \& institutional shareholding are appeared to be insignificant. The results show that a firm's size has a significant $\&$ positive association. There is a positive and insignificant association between institutional shareholding and ROA as well as a negative and significant association between managerial shareholding and ROA.

So, the alternate hypothesis is recognized testifying that there is no significant impact of corporate shareholding on a firm's performance and rejected the null hypothesis. There is a negative and insignificant association between DPO and ROA. So, the null hypothesis is recognized testifying that there is no significant effect of dividend payout on a firm's performance and the alternative hypothesis is rejected.

This research study discovered no relationship between dividends and firm performance. It was also perceived after performing out the applicable fixed-effect model based on a regression analysis that reveals insignificant association which is consistent with existing literature. The fixed-effect model shows $35.6681 \%$ of return on assets (ROA) was influenced by the independent variables; dividend payout ratio in the low growth perspective.

The $\mathrm{R}^{2}$ value of this study was 0.356681 which means that up to $35.6681 \%$ of the variation in return on assets is determined by the variation for independent variables; managerial shareholding, institutions shareholding, dividend payout ratio in the low growth perspective. This, therefore, revealed the appropriateness of the model since the high value of $\mathrm{R}^{2}$ represents no association between the dividend \& firm performance in low growth perception.

The adjusted $\mathrm{R}^{2}$ having the value of 0.284218 which explains that predictor variables were relevant and strong enough regarding the prediction of a dependent variable (ROA) and therefore designed model is strong $\&$ relevant to the fulfillment of the accomplished purpose for investigating the association between the dividend payouts and firm's performance of listed firms at Pakistan Stock Exchange. It disclosed the aptitude of the independent variables in predicting firm performance. The value of $\mathrm{P}$ shows the insignificance of the dividend payouts. It gives us a value of 0.18380 for $\mathrm{P}$ which presented that the independent variable is insignificant in inducing the firm's performance in low growth perception.

As the prime objective of this study was to establish a model with different dimensions to investigate the association and its nature between dividend payouts and firm's performance while performing out analysis concerning financial statements of firms listed at the PSX. It is concluded that there exists no association between dividend payouts and firm's performance of listed firms at the PSX from the manufacturing sector in Pakistan for the perspectives of low growth opportunities. These results are consistent with the existing studies like (Al Sa'eed, 2018; Ijaiya et al., 2014; Kadim et al., 2020; Kadioglu \& Yilmaz, 2017; Lin et al., 2017; Ruan et al., 2011).

\section{CONCLUSION}

The objective of this study is to establish a model with different dimensions to investigate the association and its nature between dividend payouts and firms' performance whereas performing out analysis for financial statements of firms listed at the PSX. This research study concluded that there exists no association between dividend payouts and firms' performance of listed firms at the PSX from the manufacturing sector in Pakistan for three perspectives under consideration. Furthermore, the research study discovered that the association is insignificant and that the model used was very helpful. In conclusion, the firm's performance does not affect the dividends payouts from different perspectives, which justifies that there is no role of dividend payouts for the firm's performance.

\section{RECOMMENDATIONS}

For current and potential investors it should not be enough matter of interest whether the firms pay a dividend or not, regarding their investing decisions. Other factors should also be considered and capital gains should be focused on by observing the market value as well. For analysts, factors other than dividends contributing to firm performance should be studied for financial analysis. The government should also try to reduce taxes on dividends for investors to protect their interests. As for new researchers, other new estimations for dividend and firm performance with new methodologies should be practised. For the management of firms, better investing and financing decisions regardless of dividends should be devised for improving the firm performance.

\section{STATEMENT OF COMPETING INTEREST}

It is certified that the authors of this research hereby declare no competing/conflicting interests regarding the publication of this paper. 


\section{AUTHOR'S CONTRIBUTION}

Taymoor Ali did the write-up of the paper, Adnan Ali Chaudhary has collected the data whereas Muhammad Kashif Khurshid did the data analysis part of the paper. All the authors significantly contributed to the paper.

\section{ACKNOWLEDGEMENT}

We would like to thank all the independent reviewers of HSSR who conducted a feasibility study of this paper.

\section{REFERENCES}

1. Agyei, S. K., \& Marfo-Yiadom, E. (2011). Dividend policy and bank performance in Ghana. International Journal of Economics and Finance, 3(4), 202-207. https://doi.org/10.5539/ijef.v3n4p202

2. Al-Sa'eed, M. A. A. (2018). The impact of ownership structure and dividends on firm's performance: evidence from manufacturing companies listed on the amman stock exchange. Australasian Accounting, Business and Finance Journal, 12(3), 107-126. https://doi.org/10.14453/aabfj.v12i3.7

3. Baba, N. (2009). Increased presence of foreign investors and dividend policy of Japanese firms. Pacific-Basin Finance Journal, 17(2), 163-174. https://doi.org/10.1016/j.pacfin.2008.04.001

4. Baker, M., \& Wurgler, J. (2004). A catering theory of dividends. The Journal of Finance, 59(3), 1125-1165. https://doi.org/10.1111/j.1540-6261.2004.00658.x

5. Bhattacharya, S. (1979). Imperfect information, dividend policy, and "the bird in the hand" fallacy. Bell Journal of Economics, 10(1), 259-270. https://doi.org/10.2307/3003330

6. Black, B., De Carvalho, A. G., Khanna, V., Kim, W., \& Yurtoglu, B. (2014). Methods for multicountry studies of corporate governance: Evidence from the BRIKT countries. Journal of Econometrics, 183(2), 230-240. https://doi.org/10.1016/j.jeconom.2014.05.013

7. Chaganti, R., \& Damanpour, F. (1991). Institutional ownership, capital structure, and firm performance. Strategic Management Journal, 12(7), 479-491. https://doi.org/10.1002/smj.4250120702

8. Chelimo, F. (2018). Effects of Regular Dividend Policy on a Firm's Financial Performance: A Case of Serena Group of Hotels in Kenya. United States International University-Africa.

9. Chen, Z., Cheung, Y.-L., Stouraitis, A., \& Wong, A. W. S. (2005). Ownership concentration, firm performance, and dividend policy in Hong Kong. Pacific-Basin Finance Journal, 13(4), 431-449. https://doi.org/10.1016/j.pacfin.2004.12.001

10. Cyril, U. M., Emeka, E. C., \& Cheluchi, I. F. (2020). Effect of Dividend Policy on Financial Performance of Consumer Goods Manufacturing Firms in Nigeria. Science Journal of Business and Management, 8(1), 7. https://doi.org/10.11648/j.sjbm.20200801.12

11. De Jong, A. (1999). An empirical analysis of capital structure decisions in Dutch firms.

12. Denis, D. J., \& Osobov, I. (2008). Why do firms pay dividends? International evidence on the determinants of dividend policy. Journal of Financial Economics, 89(1), 62-82. https://doi.org/10.1016/j.jfineco.2007.06.006

13. Easterbrook, F. H. (1984). Two agency-cost explanations of dividends. The American Economic Review, 74(4), 650-659.

14. Farsio, F., Geary, A., \& Moser, J. (2004). The relationship between dividends and earnings. Journal for Economic Educators, 4(4), 1-5.

15. Ghemawat, P., \& Caves, R. E. (1986). Capital commitment and profitability: an empirical investigation. Oxford Economic Papers, 38, 94-110. https://doi.org/10.1093/oxfordjournals.oep.a041770

16. Glen, J. D., Karmokolias, Y., Miller, R. R., \& Shah, S. (1995). Dividend policy and behavior in emerging markets: To pay or not to pay. The World Bank.

17. Gordon, M. J. (1963). Optimal Investment and Financing Policy. The Journal of Finance, 18(2), 264. https://doi.org/10.2307/2977907

18. Ijaiya, M. A., Sanni, M., Amujo, E. T., \& Suleiman, H. B. (2014). Dividend policy and financial performance: a survey of selected quoted firms in Nigeria. Centrepoint Journal, 17(1), 19-32.

19. Jensen, M. C. (2009). Agency costs of free cash flow, corporate finance, and takeovers. Corporate Bankruptcy, 76(2), 11-16. https://doi.org/10.1017/CBO9780511609435.005

20. Kadim, A., Sunardi, N., \& Husain, T. (2020). The modeling firm's value based on financial ratios, intellectual capital and dividend policy A. Kadim. 6, 859-870. https://doi.org/10.5267/j.ac.2020.5.008

21. Kadioglu, E., \& Yilmaz, E. A. (2017). Is the free cash flow hypothesis valid in Turkey? Borsa Istanbul Review, 17(2), 111-116. https://doi.org/10.1016/j.bir.2016.12.001

22. Kurniawati, T., \& Khair, A. (2020). The Impact of Capital Structure, Debt Policy, and Dividend Policy on Firm Value of Companies Listed on the LQ-45 Index. 124, 145-153. https://doi.org/10.2991/aebmr.k.200305.063

23. Lin, T. J., Chen, Y. P., \& Tsai, H. F. (2017). The relationship among information asymmetry, dividend policy and ownership structure. Finance Research Letters, 20, 1-12. https://doi.org/10.1016/j.frl.2016.06.008

24. Lintner, J. (1962). Dividends, earnings, leverage, stock prices and the supply of capital to corporations. The Review of Economics and Statistics, 44(3), 243-269. https://doi.org/10.2307/1926397

25. Litzenberger, R. H., \& Ramaswamy, K. (1979). The effect of personal taxes and dividends on capital asset prices: Theory and empirical evidence. Journal of Financial Economics, 7(2), 163-195. 
https://doi.org/10.1016/0304-405X(79)90012-6

26. M'rabet, R., \& Boujjat, W. (2016). The Relationship Between Dividend Payments And Firm Performance: A Study Of Listed Companies In Morocco. European Scientific Journal, ESJ, 12(4), 469. https://doi.org/10.190 44/esj.2016.v12n4p469

27. Mamaro, L. P., \& Tjano, R. (2019). The relationship between dividend payout and financial performance: evidence from Top40 JSE firms. The Journal of Accounting and Management, 9(2).

28. Miller, M. H., \& Modigliani, F. (1961). Dividend policy, growth, and the valuation of shares. The Journal of Business, 34(4), 411-433. https://doi.org/10.1086/294442

29. Modigliani, F., \& Miller, M. H. (1958). The cost of capital, corporation finance and the theory of investment. The American Economic Review, 48(3), 261-297.

30. Mohsin Hafeez, M., Shahbaz, S., Iftikhar, I., \& Butt, H. A. (2018). Impact of Dividend Policy on Firm Performance: (Evidence from the Manufacturing firms in Pakistan). International Journal of Advance Study and Research Work, 1(4), 1-5. https://doi.org/10.5281/zenodo.1312180

31. Muchira, K. J. (2013). Dividend payout and financial performance of manufacturing firms listed at the nairobi securities exchange. Kenyatta University.

32. Nangih, Efeeloo, \& Onuora. (2020). Journal of accounting, business and social sciences Volume 3 number 2 June 2020 ISSN 2672-4235 ( JABSS ). Journal of Accounting, Business and Social Sciences, 3(2), 36-53.

33. Olufade, S. (2018). Impact of dividend policy on firm performance in the food and beverage industry: Comparison between Nigeria and Finland.

34. Ouma, O. P., \& Murekefu, T. M. (2012). The relationship between dividend payout and firm performance: a study of listed companies in Kenya. European Scientific Journal, 8 (9).

35. Qureshi, M. A., Sheikh, N. A., \& Khan, A. A. (2015). A revisit of pecking order theory versus trade-off theory: Evidence from Pakistan. Pakistan Journal of Commerce and Social Sciences (PJCSS), 9(2), 344-356.

36. Rafindadi, A. A., \& Bello, A. (2019). Is Dividend Payment of any Influence to Corporate Performance in Nigeria? Empirical Evidence from Panel Cointegration. International Journal of Economics and Financial Issues, 9(2), 48.

37. Reddy, K., Locke, S., Scrimgeour, F., \& Gunasekarage, A. (2008). Corporate governance practices of small cap companies and their financial performance: an empirical study in New Zealand. International Journal of Business Governance and Ethics, 4(1), 51-78. https://doi.org/10.1504/IJBGE.2008.017891

38. Ruan, W., Tian, G., \& Ma, S. (2011). Managerial ownership, capital structure and firm value: evidence from china's civilian-run firms. Australasian Accounting, Business and Finance Journal, 5(3), 73-92.

39. Santos, J. B., \& Brito, L. A. L. (2012). Toward a subjective measurement model for firm performance. BARBrazilian Administration Review, 9(SPE), 95-117. https://doi.org/10.1590/S1807-76922012000500007

40. Santosa, P. W., Aprilia, O., \& Tambunan, M. E. (2020). The Intervening Effect of the Dividend Policy on Financial Performance and Firm Value in Large Indonesian Firms. International Journal of Financial Research, 11(4), 408-420. https://doi.org/10.5430/ijfr.v11n4p408

41. Senevirathna, L. D. N. (2019). Impact of dividend policy on firm performance evidence from listed companies in colombo stock exchange. GSJ, 7(10).

42. Turais, M. (2020). International Journal of Research in Commerce and Management Studies. International Journal of Research in Commerce and Management Studies, 2(2), 216-233.

43. Ugwu, C. C., Onyeka, V. N., \& Okwa, I. E. (2020). Dividend Policy and Corporate Financial Performance: Evidence from Selected Listed Consumer Goods Firms in Nigeria. Journal of Economics and Business, 3(3). https://doi.org/10.31014/aior.1992.03.03.262

44. Yao, D., Yang, H., \& Wang, R. (2011). Optimal dividend and capital injection problem in the dual model with proportional and fixed transaction costs. European Journal of Operational Research, 211(3), 568-576. https://doi.org/10.1016/j.ejor.2011.01.015

45. Zahid, M. (2020). The Impact of Capital Structure and Dividend Policy on Firm Performance: A Cross Cultural Study. SSRN Electronic Journal. https://doi.org/10.2139/ssrn.3638251

46. Zhou, X. (2001). Understanding the determinants of managerial ownership and the link between ownership and performance: Comment. Journal of Financial Economics, 62(3), 559-571. https://doi.org/10.1016/S0304$\underline{405 X(01) 00085-X}$ 